\title{
A CAIXA DE PANDORA NO ESPAÇO DO MEMORÁVEL: UMA TRADUÇÃO ÀS AVESSAS
}

\author{
Maria Angélica de Oliveira*
}

\begin{abstract}
Resumo: As fábulas fabulosas de Millôr Fernandes, despidas do caráter moralista conservador e ornadas pelo humor anárquico e irreverente, são uma tradução às avessas das fábulas do cânone clássico. Fundamentado nos pressupostos teóricos da Análise de Discurso de linha francesa, nosso artigo apresenta uma leitura discursiva da fábula fabulosa "A caixa (ou lá que outro nome tenha) de Pandora" de Millôr Fernandes a fim de evidenciar as vontades de verdade acerca dos sujeitos mulher e homem presentes nessa narrativa. Através dessa leitura constatou-se que, se, por um lado, a fábula fabulosa denuncia a relação conflituosa entre homem e mulher em nossa sociedade, por outro também denuncia sua inscrição na formação do discurso machista, revelando estereótipos negativos tanto do sujeito-mulher quanto do sujeito-homem.
\end{abstract}

Palavras-chave: Leitura discursiva. Leitor. Vontades de verdade. Memória. Desregularização.

\begin{abstract}
The humorous and irreverent "Fábulas Fabulosas" by Millôr Fernandes are an open translation of fables of the classic canon. Based on the theoretical assumptions of the French Discourse Analysis, our paper presents a discursive reading of the fabulous fable "The box (or whatever name it may have) of Pandora" in order to highlight the wills to truth about the subjects (man and woman) present in this narrative. Through this reading, it was observed that, if, on the one hand, the fabulous fable denounces the conflicting relationship between men and women in our society, on the other hand, it also denounces their affiliation in the formation of the masculine discourse, revealing negative stereotypes of both subjects.
\end{abstract}

Keywords: Discursive reading. Reader. Wills to truth. Memory. Deregulation.

\section{Primeiras palavras}

No exercício da linguagem, considerando seu poder de abstração, os sujeitos criam e recriam sua realidade, sua história, suas vontades de verdade. Desta forma, é a linguagem arena em que se constitui todo processo de produção das formas de representação das ideias, dos valores, das "verdades" de uma dada formação social. Orlandi (2001, p. 17) defende que "a vocação da linguagem é ser texto", materialidade discursiva. O texto, pensado discursivamente, é um processo significativo de natureza dialógica, interdiscursiva geradora de vários (mas não quaisquer) sentidos. Está sempre relacionado a outros textos. Sua determinação é, pois, histórica, social e ideológica. No entanto, para "acontecer", o texto prescinde da figura de um sujeito leitor, porque, segundo Gregolin (2003, p.47), "a aparição de um texto só se completa quando um leitor o insere na ordem da história deslocando-o do lugar onde jaz reclamando sentidos." Portanto, a partir de sua historicidade, enquanto posição histórico-social, o leitor resgata determinados sentidos suscitados pelo texto, sentidos possíveis em uma dada condição de produção. A partir da relação entre o interdiscurso (memória do dizer) e do intradiscurso (espaço da formulação), dos gestos de interpretação, alguns sentidos do texto serão conclamados pelo sujeito leitor a deixarem seu jazigo.

O leitor não tem liberdade para ler o que quiser em um texto, mas como puder, dadas às determinações sócio-histórico-ideológicas. De acordo com Orlandi (1998), "A interpretação, portanto, não é mero gesto de decodificação, de apreensão do sentido. Também não é livre de determinações. A interpretação se faz, assim, entre a memória institucional (arquivos) e os efeitos da memória (interdiscurso)" (ORLANDI, 1998, p. 67). Evidentemente, admitimos ser o leitor que, inscrito numa formação ideológica, a partir de

Professora Adjunta da Universidade Federal de Campina Grande. Mestre e Doutora em Letras pela Universidade Federal da Paraíba. Endereço eletrônico: mariangelicasr@gmail.com. 
determinadas condições de produção, põe em movimento, pelos gestos de interpretação, certos sentidos do texto. Entretanto, o leitor não é a origem desses sentidos. Sua ação está atrelada à ação do texto e à ação do autor, à ação do interdiscurso e do intradiscurso. Na AD, sujeitos e sentidos são efeitos de memória.

Assumindo esse lugar de sujeito leitor, posição social ideologicamente marcada, apresentamos uma leitura discursiva da fábula fabulosa "A caixa (ou lá que outro nome tenha) de Pandora", de Millôr Fernandes, a fim de evidenciar, na ordem do repetível, as vontades de verdade (FOUCAULT, 1999) que essa irreverente narrativa retrata e refrata acerca da identidade feminina presentes em nossa formação social na década de 70. Sabendo-se que toda identidade é construída a partir de sua alteridade, vontades de verdade sobre a identidade masculina serão também objeto de nossa análise.

\section{Fábula fabulosa: uma tradução às avessas}

Pelos movimentos da remanência, as fábulas da tradição, ao serem tomadas pelo sujeito autor Millôr Fernandes, distanciam-se de sua natureza de fábula, rompem com o cânone clássico, violam o gênero e metamorfoseiam-se em fábulas fabulosas. Esse sujeito autor promove uma tradução às avessas desse gênero milenar. As fábulas fabulosas de Millôr Fernandes, redefinidas sob uma ótica satírica, irreverente e subversiva, veiculam críticas mordazes à ordem social e política do país, ridicularizando as relações humanas. Essas sarcásticas historietas, na ordem do memorável (INDURSKY, 2011) refletem e refratam vontades de verdades presentes na formação social de seu contexto de produção, as décadas de 60 e de 70, especificamente. Segundo Santos (2003),

o narrar milloriano cria uma nova simbologia para a narrativa fabulística, ao desconstruir a história do texto canônico e ao inverter a sentença que veicula a moralidade da fábula clássica. Esse aproveitamento paradoxal da tradição apresenta-se como um dos fatores característicos da retórica pós-moderna. (SANTOS, 2003, p. 157).

Produzidas no esteio do pós-modernismo, período em que a sátira, o humor e a carnavalização sitiavam várias produções artístico-literárias, essas fábulas às avessas refletem a presença marcante de incredulidade em relação a quaisquer "verdades", marca identitária do pensamento pós-moderno. O sujeito autor Millôr Fernandes, através da tradução às avessas do gênero fábula, reproduz o estado de consternação às vontades de verdade promulgadas por várias instituições como a família, a igreja, o Estado, e deixa entrever, nos fios do texto, o ceticismo constitutivo do pensamento pós-moderno.

A fábula fabulosa "A caixa (ou lá que outro nome tenha) de Pandora" não é hipertexto (GENETTE, 1982) das fábulas do cânone clássico, como a maioria dessas paródicas narrativas. Seu hipotexto é o mito de Pandora. No entanto, o gênero fábula ainda lhe é constitutivo, pois essa narrativa mantém a mesma estrutura da fábula clássica, compondo-se pela narrativa, propriamente dita, e a moral. As fábulas fabulosas, pelas mãos do sujeito autor Millôr Fernandes, não suportam limites, transitam por vários gêneros. Sua natureza é híbrida. Esse sujeito autor nos oferece à leitura fábulas às avessas, carnavalizadas. Vale salientar que esse sujeito autor, no espaço do memorável, é também leitor dos textos dos quais se "apropria" e imita, transforma e reforma, estando, pois, seu "trabalho" de autoria sobre o "novo" texto inevitavelmente atrelado à sua leitura do hipotexto, que se inscreve no texto futuro, sem dele poder se desvencilhar. Esse tecer sobre um bordado tecido um novo bordado torna esse sujeito autor em um sujeito-autor-leitor. Gregolin (2001) afirma que 
"ao inscrever sua leitura no texto, o autor se mostra como sujeito de um fazer e traz o corpo para a fala enunciadora. Nesse sentido, o autor leitor se inscreve como corpo e como palavra enunciadora" (GREGOLIN, 2001, p. 65).

\section{0 mito de Pandora na ordem do repetível}

Pêcheux (1997) defende que os enunciados significam graças a dois efeitos: o efeito de encadeamento do pré-construído, o interdiscurso; e o efeito da articulação, o intradiscurso. Enquanto o interdiscurso diz respeito ao que foi dito antes, alhures, o intradiscurso diz respeito ao "que eu digo agora, com relação ao que eu disse antes e ao que direi depois" (PÊCHEUX, 1997, p. 166). Portanto, o intradiscurso, espaço da formulação, apenas será instituído na sua intrínseca relação com o interdiscurso. Salientamos, porém, que interdiscurso e intradiscurso não são "realidades" autônomas constituídas numa relação dicotômica. O intradiscurso, enquanto processo de sustentação, é efeito do interdiscurso.

Segundo Courtine $(1981)^{1}$,

l'énoncé se trouve situé d'une part dans un rapport horizontal à d'autres formulations ou sien de l'intradiscour d'une séquence discoursive, d'autre part dans un rapport vertical à des formulations repérables dans d'autres séquences discursives, dans l'interdiscours d'une FD.(COURTINE, 1981, p. 44)

A partir desta perspectiva, o interdiscurso é condição sine qua non do discurso enquanto conjunto de enunciados provenientes de uma mesma formação discursiva. A concepção de interdiscurso, adotada no seio da AD, assemelha-se ao conceito de dialogismo, que consiste na relação que todo enunciado mantém com enunciados outros, como já havíamos mencionado. Portanto, na perspectiva da $\mathrm{AD}$, podemos pensar na ideia de um dialogismo interdiscursivo (CHARAUDEAU et al., 2004, p. 161), caracterizando, assim, o diálogo inevitável entre os discursos. Diante do exposto, podemos dizer que o interdiscurso está para o discurso, tendo em vista que todo discurso é atravessado pela interdiscursividade, assim como o intertexto está para o texto, levando em consideração que todo texto é atravessado pela intertextualidade, segundo a visão de Júlia Kristeva.

Kristeva (1968) remete a uma propriedade constitutiva do texto como um todo. Num sentido amplo, essa noção de intertextualidade poderá ser comparada àquela de interdiscursividade discutida anteriormente, pois, assim como todo discurso reclama o interdiscurso, todo tex to reclama um intertexto. No entanto, de acordo com Orlandi (1999, p. 34), "o interdiscurso é da ordem do saber discursivo, memória afetada pelo esquecimento, ao longo do dizer, enquanto o intertexto restringe-se à relação com outros textos". Nessa relação intertextual, o "esquecimento" não é estruturante como o é para o interdiscurso. Então, podemos dizer que a ideia de interdiscursividade recobre aquela de intertextualidade, mas a recíproca não se faz verdadeira.

A partir da teoria da intertextualidade, fundada através da concepção bakhtiniana de dialogismo, o texto é compreendido, no seio dos estudos literários, como uma voz que dialoga

\footnotetext{
1 O enunciado acha-se situado, de um lado, em relação horizontal a outras formulações no interior do intradiscurso de uma sequência discursiva, de outro lado, em relação vertical a formulações localizadas em outras sequências discursivas, no intradiscurso de uma FD. (Tradução: Prof. Gabriel Alves de Oliveira).
} 
como outros textos, funcionando também como ecos das vozes de seu tempo, de sua história, revelando os valores, as crenças, os pré-conceitos de um dado grupo social. Gérard Genette, tomado por esta concepção dialógica de texto, inaugura, no universo dos estudos literários, sua teoria da transtextualidade. Através da metáfora do palimpsesto, Genette (1982) ilustra a relação entre os textos, as relações transtextuais. O palimpsesto era uma prática, sobretudo, medieval de escrever em pergaminhos. Como os pergaminhos eram escassos, era preciso reaproveitá-los, escrevendo um texto sobre outro texto. Apagava-se, então, o texto anterior para a escrita de um novo texto, deixando entrever a escrita do primeiro. Para Genette (1982), vem daí a denominação de palimpsesto para textos escritos que retomam e revelam textos outros. Essa relação palimpsesta em Genette (1982) será denominada de transtextualidade.

Segundo Genette (1982), a transtextualidade diz respeito a tudo o que põe um texto em relação, seja manifesta ou secreta, a outros textos. O conceito de transtextualidade defendido pelo autor poderá corresponder àquele de intertextualidade apresentado por Kristeva (1968), a partir do qual Genette desenvolve sua teoria da transtextualidade. No entanto, para Genette (1982), a intertextualidade não está relacionada a toda relação entre os textos, mas a um tipo específico de relação transtextual. A intertextualidade, nesse autor, não alcança a amplitude antes defendida por Kristeva (1968). Para ele, a intertextualidade diz respeito à presença efetiva de um texto em outro texto. Seriam exemplos de intertextualidade: a citação, o plágio, a alusão.

Para Genette (1982), todas as obras literárias seriam hipertextuais. Não há, na sua concepção, obra literária que não reclame, de alguma forma, outra obra. Assim como, para Kristeva (1968), todo tex to literário seria marcado pela intertextualidade, para Genette (1982) toda obra literária é atravessada pela hipertextualidade. Vale salientar que as relações transtextuais não atuam de maneira estanque, mas muitas vezes, de forma conjunta.

Sant'Anna (1987) apresenta, basicamente, dois tipos de intertextualidade: a intertextualidade das semelhanças e a intertextualidade das diferenças. No primeiro caso, o texto incorpora o intertexto com o objetivo de segui-lo, apresentando o valor de captação. No segundo caso, o intertexto incorpora o texto fonte, seu hipotexto, para subverter seus dizeres. Apresenta-se, portanto, neste caso, o valor de subversão. Como exemplo de intertextualidade das semelhanças, temos o argumento de autoridade e a paráfrase; como exemplo da intertextualidade das diferenças, temos a ironia e, principalmente, a paródia, que será marca identitária das fábulas fabulosas de Millôr Fernandes.

Pensando a heterogeneidade que constitui todo e qualquer dizer, a partir do conceito bakhtiniano de dialogismo, Authier-Revuz transporta para a AD a concepção de heterogeneidade enunciativa. Segundo Authier-Revuz (1982), a heterogeneidade enunciativa pode ser classificada como mostrada ou constitutiva. A heterogeneidade mostrada corresponde a uma presença localizável de um discurso em outro no fio do texto, o que altera sua suposta unicidade. Quando num texto encontramos, por exemplo, o discurso direto, temse um exemplo da heterogeneidade mostrada. Poderíamos dizer que aqui, na heterogeneidade mostrada, está inscrita a polifonia, tendo em vista que recuperamos marcas do diálogo no fio do texto. Esta heterogeneidade é nomeada marcada quando apresenta, explicitamente, através de marcas linguísticas, a presença do outro no discurso, como, por exemplo, o emprego de aspas, discurso direto, negação, discurso indireto etc., ou não-marcada, quando a presença do outro não está tão explicitamente delimitada. É localizável, às vezes, graças ao conhecimento cultural do co-enunciador ou sobre a base de índices textuais, como, por exemplos: discurso indireto livre, imitação, ironia, alusões.

Como é possível observar através dessas concepções de interdiscurso, intertexto, dialogismo, heterogeneidade enunciativa, dentre outras, "a repetibilidade está na base da produção discursiva. É ela que garante a constituição de uma memória social que sustenta os 
dizeres, pois só há sentido porque antes já havia sentido" (INDURSKY, 2011, p 88.). Ainda segundo Indursky (2011), a repetibilidade estando na base da produção discursiva acontece através da regularização dos sentidos, processo mais comum; e da desregularização dos sentidos, processo menos presente. Acrescenta esta autora acerca da repetibilidade, "entretanto, essa repetibilidade não é capaz de cristalizar os sentidos, pois à força de repetir, os sentidos vão deslizando e se transformando" (INDURSKY, 2011, p. 88). Vejamos como, no espaço da desregularização dos sentidos, na ordem do repetível, o sujeito autor leitor Millôr Fernandes (re)constrói o Mito de Pandora, refletindo e refratando as vontades de verdade presentes em nossa formação social. Tomemos para isso a fábula fabulosa:

\section{A CAIXA (OU LÁ QUE OUTRO NOME TENHA) DE PANDORA}

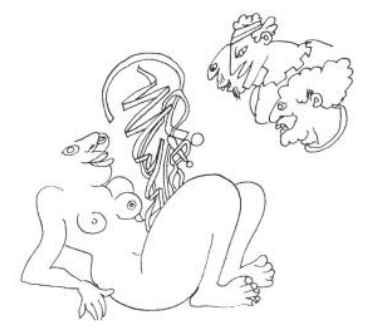

No tempo em que Prometeu usava-se apenas como nome próprio e não como verbo compondo uma frase deceptiva: "Prometeu e não cumpriu", era tudo home cum home. A Terra ainda estava vazia de mulheres. Não estou dizendo que isso fosse bom ou ruim, mas feminismo não tinha não. Pensando bem, até que podia ser bom porque hoje, depois do feminismo, tem muito home aí já jogando as muié pra escanteio e muita muié também fazendo o mesmo com os home, e deve ser porque isso é bom, não é mesmo? Digam vocês aí que entendem.

Mas o caso é que Prometeu juntou a moçada na praça - só tinha uma e se chamava Ágora - e disse que todo mundo ia ficar besta com um número que ele ia fazer, uma coisa! Deu um pulo quando um raio de sol ia passando baixinho e, pronto, roubou o fogo. A maior parte dos caras ficou meio assim sobre o decepcionado porque estava mesmo é esperando que ele roubasse do céu uma dona boa, uma baita deusa, pois, enquanto os humanos viviam no ora veja, os deuses lá em cima andavam cercados das minas e das gatinhas - literalmente nas nuvens, num machismo adoidado.

Mas, quando Prometeu ficou com o fogo na mão, orgulhoso de sua bravata, Júpiter nem conversou - decidiu punir os mortais, vejam só!, dando-lhes exatamente o que eles queriam - uma mulher! - só pra eles aprenderem o que era bom.

E ali mesmo na praça, bonita como um chafariz e jorrando pipi como um desses ornamentos arquitetônicos, surgiu Pandora ${ }^{1}$. As exclamações, ao vê-la cair do céu, foram as mais naturais possíveis:

- Olha o arco-íris!

- Que é que é isso, pombas?

- Pombas? Bom nome pro bicho.

- Macia às pampas, sobretudo aqui atrás.

- Topless, olha!

- O que é que ela está escondendo na caixinha?

Sim porque, além de todas as suas qualidades, Pandora tinha uma caixinha negra, de forma triangular, que Deus (Zeus, Júpiter) tinha lhe dado, recomendando que não a abrisse pra ninguém nunca, conservasse a sua - 
dela, caixa - virgindade, que aliás, pra maior segurança, vinha lacrada com um hímen epitelial.

Mas, sabe como é home, né? Sempre naquela de oprimir a mulher. Tanto pediram: "Abrel Abrel" "Ah mostra!" "Nenhum de nós tem um igual!" "Hi, o que é que tem dentro? Aposto que você sabe" - que Pandora hesitou, hesitou, mas... Pois é, não resistiu mesmo quando um centurião, mais afoito, bolou uma forma carinhosa que ia durar séculos: "Abre, meu bem!"

Pandora abriu a sua caixinha e, pronto, os males do mundo que estavam lá dentro - a luxúria, a inveja, o medo, o cheque sem fundo e a impontualidade - escaparam todos e povoaram a Terra pra sempre. Pandora ainda fechou as pernas - onde tinha colocado a caixinha - a tempo de reter a esperança, uma florzinha pequenininha cor-de-rosa, muito suscetível, espécie de Maria semvergonha.

Por isso até hoje a Esperança só dá no escuro e os homens vivem atrás dela aos tropeções. Mas não desistem.

MORAL: A SUPERPROTEÇÃO NUM TÁ CUM NADA.

1. Quer dizer, a intenção de Júpiter era Prometeu casar com Pandora e quebrar a cara. Mas, como Prometeu nem deu bola, ele estava noutra, Júpiter, fulo dentro da roupa, mandou pendurar Prometeu no Cáucaso, condenando-o a ter o fígado devorado por um abutre durante 30.000 anos. Mas Hércules, o super-herói, matou o abutre e libertou Prometeu trinta anos depois: o que dá $99.900 \%$ de diminuição da pena. É o que eu chamo de uma anistia!

Iniciemos nossa leitura discursiva observando o título da fábula fabulosa: A Caixa (ou lá que outro nome tenha) de Pandora. O título apresenta duas vozes que se cruzam: a "voz" da irreverência (voz do sujeito em sua função-autor) e a voz do outro (do hipotexto). A "voz" da irreverência encaminha o sujeito leitor ao encontro do novo, do espaço da formulação. Esta voz da irreverência aparece no trecho entre parênteses: (ou lá que outro nome tenha). O restante do título - A Caixa de Pandora - confirma a presença do mesmo, o retorno do mito, que é a essência fundadora do novo. Lugar da memória discursiva, "que faz aí ressoar os ecos de uma memória coletiva, social" (INDURSKY, 2011, p. 87). Essas marcas denunciadoras das presenças do já-dito e do inauguramento do dizer estão situadas no espaço da heterogeneidade mostrada não marcada. Para que sejam "lidas", elas exigem o retorno ao arquivo, memória institucional, compreendido como o "sistema geral da formação ${ }^{2}$ e transformação dos enunciados” (FOUCAULT, 1972, p. 162).

Durante toda a narrativa, estão inscritas a voz do "mesmo" e a voz do "outro". Estas vozes não se cruzam de forma pacífica, mas a partir de um jogo de reversibilidade do dizer institucionalizado. Há, portanto entre estas vozes, um "conflito", visto que a fábula fabulosa é uma paródia. Na fábula fabulosa, há uma "desconstrução" dos sentidos já ditos, inaugurando, a partir deles, novos sentidos. Não é uma "desconstrução" que apaga a voz do hipotexto, mas que tem um efeito de deslocamento, um gesto de interpretação dos sentidos já existentes, cuja referência está no funcionamento discursivo. Este efeito de deslocamento é denominado por Maingueneau (1996) de détournement, termo usado para designar alteração na forma ou conteúdo do texto, com o propósito, neste caso, de subversão. O efeito de deslocamento, além de reafirmar a relação palimpsesta, confirma o "trabalho" de "tecedura" do sujeito autor leitor Millôr. A fábula fabulosa, além do gênero fábula, agora dialoga também com outro gênero, o gênero mito, confirmando mais uma vez sua natureza híbrida.

\footnotetext{
${ }^{2}$ Grifos nossos.
} 
A partir do efeito de deslocamento, trabalha-se o espaço de ressignificação do discurso fundador. Entretanto, esse trabalho de ressignificação só será percebido como ironia e sátira ao discurso fundador no espaço do memorável. De acordo com Indursky (2011), “é preciso que o sentido primeiro ressoe junto com os novos sentidos, funcionando como uma presença-ausente. É o memorável que aí ressoa. Não dá para interpretar uma atualidade sem mobilizar a memória" (INDURSKY, 2011, p. 86).

O principal fato responsável pela referência ao hipotexto, evidentemente, é o próprio enredo, o envio de Pandora à Terra com o intuito de punir os mortais. A mulher figurativizando o mal: aquilo que é ruim, a "desgraça" da humanidade situa-se no espaço da história, da memória. Servir de figura para o que é negativo e pecaminoso é algo que acompanha a figura feminina desde muito tempo, sobretudo através do discurso religioso, disseminador de jogos de verdade preconceituosos e discriminatórios. Esses jogos de verdade, assim como esta fábula fabulosa, filiam-se à formação do discurso machista, gestado no seio de uma sociedade machista. Personagens como Prometeu, Júpiter e Hércules também são pontos que nos encaminham ao hipotexto. No entanto, quando o sujeito-autor da fábula fabulosa faz menção de forma irônica ao feminismo:

SD1 - Não estou dizendo que isso fosse bom ou ruim, mas feminismo ${ }^{3}$ não tinha não. Pensando bem, até que podia ser bom porque hoje, depois do feminismo, tem muito home aí já jogando as muié pra escanteio e muita muié também fazendo o mesmo com os home, e deve ser porque isso é bom, não é mesmo?,

percebemos "nitidamente" que o diálogo nesse momento não é com o hipotexto, mas com o contexto sócio-histórico, em que a fábula fabulosa foi produzida, final da década de 70 , período do ressurgimento do feminismo no Brasil. Na referência irônica ao feminismo, a função-autor, mais uma vez, revela a inserção deste enunciado na FD do discurso machista, que responde como uma estratégia de resistência, ao movimento feminista que ganhava forças naquele período histórico. Segundo Foucault (1995), as lutas contemporâneas giram em torno da busca por novas identidades, contra a submissão da subjetividade. Diz o estudioso:

Talvez, o objetivo hoje em dia não seja descobrir o que somos, mas recusar o que somos. Temos que imaginar e construir o que poderíamos ser para nos livrarmos deste "duplo constrangimento" político, que é a simultânea individualização e totalização própria às estruturas do poder moderno. (FOUCAULT, 1995, p. 239).

O feminismo, como movimento da época, surge, pois, como uma forma de constituir outra identidade para o indivíduo feminino, diferente daquela imposta pelo mundo machista, de sujeito fraco, serviçal, subordinado às ordens do homem; insurge-se como busca da identidade de sujeito independente portador dos mesmos direitos que o sujeito homem. Evidentemente, como relação de poder, essas lutas pela busca de uma nova identidade não acontecem de forma pacífica, apresentam resistência. $O$ discurso contra o feminismo, depreciando-o, ridicularizando-o, é uma estratégia de resistência a este movimento, o que reafirma sua força de consolidação, seu lugar na sociedade.

Analogamente ao mito, Prometeu roubou o fogo do astro rei, mas os caras da nossa fábula fabulosa ficaram decepcionados, pois esperavam que o herói grego "roubasse do céu uma dona boa, uma baita deusa". Novamente os textos divergem, revelando dizeres cristalizados de uma sociedade machista - dona boa/ baita deusa - que vê a mulher como

\footnotetext{
${ }^{3}$ Grifos nossos.
} 
objeto de desejo sexual masculino, por que não dizer como "um objeto arquitetônico". Além de Pandora ser bonita como "um chafariz", ter "nádegas macias", fazer topless, tinha uma "grande" qualidade, era possuidora de uma "preciosa caixinha negra de forma triangular", que não se sabe bem o nome - "(ou lá que outro nome tenha)", pois muito são os nomes dados à genitália feminina. Ao apresentar tais características como todas as qualidades de Pandora, o sujeito-enunciador, além de confirmar a inscrição da fábula fabulosa numa formação do discurso machista, de forma cômica e irônica, desnuda valores ideológicos de nossa sociedade, uma sociedade em que a mulher é geralmente vista como objeto sexual. Como afirma Figueiredo (1998, p. 194), "a mulher em nossa sociedade desempenha papel de objeto de cama, mesa e banho para o consumo de homem que, ainda, conserva uma organização de sociedade patriarcal".

A ironia, marca identitária dessa autoria, circula por todo o enunciado, chamando a atenção do sujeito leitor, assim como "obrigando-o" a integrar-se ativamente à construção dos sentidos do texto, como já dissemos, a partir do discurso documental, pois o procedimento irônico "obriga" o leitor a deixar os limites do texto devido à sua dimensão intertextual e interdiscursiva. A sequência discursiva abaixo exemplifica a natureza irônica dessa narrativa:

SD2 - Pandora tinha uma caixinha negra, de forma triangular, que Deus (Zeus, Júpiter) tinha lhe dado, recomendando que não a abrisse pra ninguém nunca, conservasse a sua - dela, caixa - virgindade, que aliás, pra maior segurança, vinha lacrada com um hímen epitelial.

Ironicamente, nesse trecho, o sujeito-autor faz referência ao discurso religioso, castrador por excelência da sexualidade feminina. A virgindade sempre foi um tabu para a Igreja. A mulher deveria casar-se pura e casta, sobretudo quando nos reportamos ao período em que foi escrito o enunciado em questão. A década de 70, muito mais que hoje, estava imbuída desse discurso conservador e machista, dessa vontade de verdade que defendia que a honra da mulher estava intimamente relacionada à sua virgindade. No início do século XIX, a mulher, como propriedade, deveria ser entregue ao seu "proprietário" sem que nenhum outro a tivesse "tocado", se não isso daria ao seu dono o direito legal de anular o casamento perante a lei dos homens e a "lei" de Deus. Como salienta o sujeito-autor, Os homens "sempre estiveram naquela de oprimir a mulher". Através do procedimento linguístico-discursivo da ironia, o sujeito-enunciador da fábula fabulosa denuncia a posição de "subordinação" da mulher numa sociedade que se diz democrática e livre, denunciando também o caráter opressor e manipulador dos homens que, em nossa sociedade, apesar de todas as conquistas femininas, ainda ocupam o lugar de "dominação". Foi justamente como resposta a essa dominação, como estratégia de resistência, que nasceram os movimentos feministas muito presentes no final da década de 70. Na fábula fabulosa, ambos os sujeitos homem e mulher são identificados através de estereótipos negativos.

As personagens escolhidas pelo autor a participarem do enredo figurativizam a delimitação dos lugares sociais de dominação e de subordinação. Vale salientar que a dominação nem sempre se dá pela força, pela coerção. Isto é uma característica do poder moderno, pois, segundo Foucault (1999), o poder moderno caracteriza-se não mais como instância repressiva e transcendente, mas como instância de controle através da manipulação sutil que envolve o indivíduo, ao invés de dominá-lo abertamente. A manipulação masculina nos é apresentada de forma evidentemente irônica quando Pandora, não resistindo ao assédio do centurião, abre sua "preciosa" caixinha negra. A próxima sequência discursiva nos mostra a "fraqueza" de Pandora e do Centurião: 
SD3 - Pandora hesitou, hesitou, mas... Pois é, não resistiu mesmo quando um centurião, mais afoito, bolou uma forma carinhosa que ia durar séculos: “Abre, meu bem!"

Ao abrir a caixinha negra, a Pandora da fábula fabulosa deixa escapar: "a luxúria, a inveja, o medo, o cheque sem fundo e a impontualidade". Todos esses "males" são popularmente atribuídos sobretudo à figura feminina. São as mulheres que têm fama de luxuriosas, invejosas, medrosas, gastadeiras. Este dizer que culpa a mulher por todos os males do mundo, como já foi mencionado, está inscrito em nossa história, situa-se no espaço da memória discursiva que é "regionalizada, circunscrita ao que pode ser dito em uma FD e, por essa razão, é esburacada, lacunar" (INDURSKY, 2011, p. 87, grifos da autora). Na Bíblia, por exemplo, há essa imagem da figura feminina como a perdição da humanidade. É por culpa de Eva, a mulher, que o homem é expulso do paraíso e deverá sofrer os males do mundo. Mais uma vez, revestido pelo irônico, a fábula fabulosa revela as relações sociais do contexto sócio-histórico. Reflete e refrata as vontades de verdade sobre o sujeito mulher que perdurou durante muito tempo em nossa sociedade.

O mito de Pandora, assim como tantos outros escritos, veicula valores ideológicos negativos à figura feminina. É por culpa de Pandora, uma mulher, que os males povoam a Terra. A discriminação à mulher não é apenas veiculada através do discurso mitológico, mas por vários outros discursos, como, por exemplo: o discurso jurídico, jornalístico, publicitário e, sobretudo, o discurso religioso. Basta que lembremos a figura de Eva ou da mulher de Ló. Cunha (2003) afirma que:

essa discriminação tem resquícios ou podemos dizer são cicatrizes que a sociedade carrega e que é marcada, ainda, por valores ideológicos que são transportados através de uma herança histórica materializada e veiculada por discursos que se fazem presentes nas mais variadas tipologias textuais. (CUNHA, 2003, p. 76)

Nessa relação bivocal, dialógica, o hipotexto é retomado, como vimos, não com a intenção de conservar seus valores, mas com a intenção da subversão, que se institui através do discurso irônico, próprio do enunciado parodístico. Há uma desregularização dos sentidos. No entanto, essa subversão, essa desregularização dos sentidos, assim como as denúncias instauradas pela paródia, só será compreendida se o sujeito leitor perceber a sua relação bivocal, dialógica, intertextual, pois "o discurso irônico convoca seu enunciatário, exige dele uma construção interpretativa complexa" (BRAIT, 1996, p.109). Ao deixar falar a voz do conquistador - "Abre, meu bem!" -, instaura-se não só a ironia, mas também uma denúncia contra o poder masculino em conquistar a mulher. Há, no contexto sócio-histórico-cultural, não só dos anos 70, mas no atual, a ideia de que a mulher é sexo frágil. O ceder ao apelo "romântico" do homem e abrir a "caixinha negra" deixa entrever a "fragilidade" feminina ante o "carinho" masculino. Carinho esse aqui ironizado pela paródia. Através das artimanhas da ironia, o enunciado revela-nos que basta o homem se fazer de "romântico" e "apaixonado" que a mulher acredita e se entrega aos seus caprichos. $\mathrm{O}$ "bolar uma forma carinhosa que ia durar séculos" retoma valores ideológicos que estão na sociedade e que dizem que o homem "sabe" enganar a mulher e que a mulher é ingênua e frágil para acreditar na paixão masculina. Enquanto ao sujeito mulher são delegadas características como fragilidade, ingenuidade, inferioridade, ao sujeito homem não são destinadas características não menos negativas. A esse sujeito são destinados traços como: falsidade, egoísmo, superficialidade. Ambas as identidades são apresentadas por lentes de estereótipos que as depreciam, vontades de verdade 
que estão presentes ainda hoje na formação social. Como é sabido, o mal dos estereótipos não é que sejam mentiras, mas que são incompletos, que apresentam uma leitura única de dadas identidades.

Se, por um lado, a fábula fabulosa revela a dominação masculina, desnuda o preconceito contra a mulher em nossa sociedade, por outro, também denuncia, nos fios do texto, sua inscrição na formação do discurso machista, principalmente através da relação paratextual. Estamos nos referindo à afirmação presente na nota final, em forma de comentário, cicatriz denunciadora da inscrição da narrativa nesta formação discursiva - "Quer dizer, a intenção de Júpiter era Prometeu casar com e quebrar a cara" - denunciando também a objetivação de sujeito-autor-Millôr, num sujeito que ocupa o lugar social de machista. Essa objetivação pode ser confirmada em outros enunciados do mesmo sujeitoautor. Vejamos:

SD4 - Uma linda mulher de quarenta anos: cara e coroa. (FERNANDES, Millôr definitivo; a bíblia do caos, 2002, p. 382).

SD5 - Quando não tinha feminismo, mulher dava muito trabalho. Hoje dá muito mais. Não dá? Dá. (FERNANDES, 100 fábulas fabulosas. 2003, p. 102).

SD6 - A arte e a natureza (masculina) deveriam se aliar natural e artisticamente para a criação da nova mulher (FERNANDES, $O$ livro vermelho dos pensamentos de Millôr, 2000: p. 98).

SD7 - Como sexo as mulheres são insuportáveis, mas na hora do sexo, não tem nada melhor (FERNANDES, Novas Fábulas Fabulosas, 1978, p. 86).

SD8 - O meio faz o homem e desfaz as mulheres (FERNANDES, Fábulas Fabulosas, 1963, p. 26).

Na fábula fabulosa, assim como no mito, a única coisa que restou na caixinha negra foi a esperança. A partir da concepção mitológica, é essa a justificativa de o ser humano continuar vivendo e lutando por seus ideais. Apesar de todos os males povoarem a Terra, resta-lhes a esperança. No entanto, a esperança mencionada na fábula fabulosa diverge, e muito, daquela citada no mito. $\mathrm{O}$ autor refere-se à genitália feminina e não ao sentimento citado no mito. Instaurando mais uma vez o seu caráter cômico e irreverente, reafirmando o dizer às avessas da paródia, ratificando também a vontade de verdade presente em nossa formação social que identifica o homem como aquele que vive em busca apenas do sexo. Dizer ratificado no parágrafo seguinte através do duplo sentido que habita o verbo dar da proposição: "Por isso até hoje a Esperança se dá no escuro e os homens vivem atrás dela aos tropeções”. Como afirma Indursky (2011), é nesse espaço que o memorável ressoa, há o deslizamento dos sentidos, sua desregularização, mas a interpretação só é possível devido à memória discursiva. O sujeito autor retoma o hipotexto para (res)significá-lo, (des)construílo, inaugurando nos sentidos já existentes, sentidos outros, nessa relação paratextual, irão, numa incessante "luta de vozes", construiu o "novo" no "mesmo."

De acordo com Genette (1982), a paratextualidade relaciona-se às marcas que cercam o texto, sua periferia, como título, subtítulo, prefácio, ilustração, notas marginais, epígrafes. Lendo essas marcas paratextuais, encontramos mais uma vez o diálogo dessa narrativa com seu contexto sócio-histórico. Vejamos essas marcas, retornemos às relações paratextuais, às notas finais. Ao comentar o castigo de Prometeu, dado por Júpiter, mais uma vez há uma referência ao contexto sócio-histórico, a vozes sociais. Comentando o caráter da anistia concedida a Prometeu, o sujeito-autor está ironizando o caráter da anistia naquela 
época de repressão, de prisões políticas, de cassações. Nos últimos anos da década de 70, a campanha da anistia ganhou força dentro e fora do país. Este comentário reafirma a natureza de denúncia dessas fábulas fabulosas, as quais, como hipotexto, pela teoria da transtextualidade, têm valor de comentário. Numa perspectiva foucaultiana, Gregolin (2003, p. 52) afirma que, "pelo procedimento do comentário, há um retorno incessante a certos textos, que os presentifica e faz com que eles se conservem na memória de uma cultura". $\mathrm{Na}$ sua discursividade, as fábulas fabulosas trazem sempre de volta à memória cultural a imagem das fábulas da tradição, mesmo que de forma às avessas, mesmo que para parodiá-las.

A ilustração paratextual presente no início da fábula fabulosa também é marca denunciadora da característica às avessas dessa narrativa. $\mathrm{O}$ desenho humorístico e caricatural evidencia o dizer paródico da narrativa, sua natureza satírica, às avessas. O diálogo com o não-verbal constrói efeitos de sentidos na produção do discurso anárquico, subversivo e irreverente que dessa narrativa fazem morada.

$\mathrm{Na}$ tecedura de um bordado às avessas, esse sujeito autor mostra uma subjetividade marcada pela irreverência, pela ironia e pela carnavalização, inscrevendo-se por rastros, por assinaturas que o identificam como sujeito autor leitor Millôr Fernandes. Essas assinaturas identificam sua autoria, assim como a formação discursiva na qual essas pequenas narrativas se situam, a formação do discurso irônico, subversivo.

\section{Palavras derradeiras}

Todo texto conclama um sujeito leitor para resgatar os seus sentidos, as vozes que se cruzam naquele lugar. Evidentemente que nem todas as vozes poderão ser ouvidas. Assim como nem tudo poder ser dito, pois a linguagem é marcada pelo impossível do dizer (PÊCHEUX, 1997), nem tudo pode ser lido, porque a leitura é mediada pelas condições sócio-histórico-ideológicas de sua produção. Para que as vozes de subversão e de paródia dessa fábula fabulosa sejam ouvidas, faz-se necessário que o sujeito leitor reconheça seu hipotexto, o Mito de Pandora, como também o contexto sócio-histórico com o qual essa intrigante narrativa dialoga, a década de 70. Segundo Gregolin (2001, p. 70), "o texto é apenas uma rota que indica outros lugares para interpretação. Daí advêm os seus graus de legibilidade, porque essa rota não é visível para todos os leitores, em todos os momentos". A fábula fabulosa em questão é uma rota legível para um leitor que capte os jogos metafóricos e paródicos que se situam na fronteira do humor e da sátira.

Ao tecer "A caixa (ou lá que outro nome tenha) de Pandora", o sujeito autor leitor Millôr Fernandes atualizou a fábula do cânone clássico conforme as condições de produção e sua época. No espaço da desregularização (INDURSKY, 2011), transformando, renovando e deslocando os sentidos do mito, mas mantendo-o no espaço da memória cultural, esse sujeito autor, nos fios do "novo" bordado tecido, refratou e retratou, através do discurso paródico, aspectos referentes às identidades feminina e masculina de nossa formação social da década de 70. Através da fábula fabulosa, esse sujeito autor denunciou a relação desigual e intolerante entre os sujeitos homem e mulher nessa formação social. Denunciando a submissão feminina, o sujeito enunciador ratificou a opressão masculina. Ao revelar os estereótipos acerca do sujeito mulher presentes no contexto brasileiro da década de 70: sexo frágil, ingênua, fútil, Millôr Fernandes retratou também os estereótipos do sujeito homem: egoísta, manipulador, superficial, dominado pelo sexo. Nesta narrativa, as identidades: feminina e masculina são vistas por lentes de estereótipos que as depreciam, por vontades de verdade que muitas vezes são usadas para justificar práticas intolerantes e preconceituosas tanto em relação ao sujeito mulher quanto ao sujeito homem. 
Através da prática da leitura discursiva, pretendemos auxiliar na desconstrução de estereótipos negativos acerca dessas identidades, filiamo-nos na luta contra leituras únicas responsáveis pela manutenção de preconceitos negativos que ratificam a intolerância a diversas identidades, dentre essas, mulher e homem.

\section{Referências}

AUTHIER-REVUZ, J. Hétérogeneité montrée et hétérogeneité constitutive: éléments pour une approche de l'autre dans le discours. DRLAV. Paris, n. 26, 1982.

BIZZOCCHI, A. O sentido lingüístico da vida. In: Língua portuguesa. São Paulo: Editora Segmento, ano 4, n. 52, fev. 2010.

BRAIT, B. (org.) Ironia em perspectiva polifônica. São Paulo: Pontes, 1996.

CHARAUDEAU, P.; MAINGUENEAU, D. Dicionário de Análise do Discurso. Trad. (coord.) Fabiana Komesu. São Paulo: Contexto, 2004.

COURTINE, J-J. Analyse de discours politique. Le discours communiste adressé aux chrétiens. In: Langages, 62. Paris: Didier-Larousse, 1981.

FERNANDES, M. Fábulas Fabulosas. 14ª ed. Rio de Janeiro: Nórdica, 1963. Novas Fábulas Fabulosas. $5^{\text {a }}$ ed. Rio de Janeiro: Nórdica, 1978.

FIGUEIREDO, I. de L. O discurso da propaganda: construção ideológica? In: Graphos, v. III, n. 1, p. 186-196, jan.1998.

FOUCAULT, M. A arqueologia do saber. Trad. Luiz Felipe Baeta Neves. Petrópolis: Vozes, 1972.

O sujeito e o poder. In: DREYFUS. H.; RABINOW, P. Michel Foucault: uma trajetória. Para além do estruturalismo e da hermenêutica. Rio de Janeiro: Forense, 1995.

Microfísica do poder. Trad. Roberto Machado. 14ª ed. Rio de Janeiro: Graal,1999.

GENETTE, G. Palimpseste: la littérature au second degré. Paris: Seuil, 1982.

GREGOLIN, M. do R. (Org.). Discurso e mídia: a cultura do espetáculo. São Paulo: Claraluz, 2003.

GREGOLIN, M. do R. (et al.) Análise do discurso: entornos do sentido. Araraquara: UNESP, FCL, 2001.

KRISTEVA, J. O texto fechado. In: BARTHES, R. et al. Lingüística e literatura. Trad. Isabel Gonçalves e Margarida Barahona. São Paulo: Martins Fontes, 1968. 
A linguagem, a língua, a fala, o discurso. In:

História da linguagem. São Paulo, Martins Fontes, 1969.

INDURSKY, F. A memória na cena do discurso. In: INDURSKY, F. et. al. (Orgs.). Memória e história na/da Análise do Discurso. Campinas: Mercado de Letras, 2011.

MAINGUENEAU, D. Les termes clés de l'analyse du discours. Paris: Seuil, 1996.

ORLANDI, E. P. Análise do discurso: princípios e procedimentos. São Paulo: Pontes, 1999. (org.) A leitura e os leitores. Campinas: Pontes, 1998.

PÊCHEUX, M. Semântica e discurso: uma crítica à afirmação do óbvio. $3^{\mathrm{a}}$ ed. Campinas: UNICAMP, 1997.

SANT’ANNA, A. R. de. Paródia, paráfrase e cia. São Paulo: Ática, 1987.

SANTOS, I. dos. Homens, raposas e uvas: a fábula na literatura. Blumenau: Edifurb, 2003.

Recebido em: setembro de 2013.

Aprovado em: outubro de 2013. 